Article

\title{
Effect of Calcination Temperature on Structural Properties and Catalytic Performance of Novel Amorphous NiP/H $\beta$ Catalyst for n-Hexane Isomerization
}

\author{
Jinshe Chen ${ }^{1, *} \mathbb{C}$, Lijun Zhu ${ }^{2}$, Yuzhi Xiang ${ }^{2}$ and Daohong Xia ${ }^{2, *}$ \\ 1 College of Safety and Environmental Engineering, Shandong University of Science and Technology, \\ Qingdao, Shandong 266590, China \\ 2 State Key Laboratory of Heavy Oil Processing, China University of Petroleum, Qingdao 266580, China; \\ zhulj2002@163.com (L.Z.); xiangyzh@163.com (Y.X.) \\ * Correspondence: chenjins2010@163.com (J.C.); xiadh@upc.edu.cn (D.X.)
}

Received: 13 June 2020; Accepted: 15 July 2020; Published: 21 July 2020

\begin{abstract}
To study how calcination temperature influences the structural properties and catalytic performance of a novel amorphous $\mathrm{NiP} / \mathrm{H} \beta$ catalyst, amorphous $\mathrm{NiP} / \mathrm{H} \beta$ catalysts calcined at different temperatures were prepared for $\mathrm{n}$-hexane isomerization. The optimum calcination temperature was determined, and the effect of calcination temperature on the structural properties of the catalysts was investigated using different characterization methods, such as XRD, TPD and so on. It was found that the optimum calcination temperature was $200^{\circ} \mathrm{C}$. Simultaneously, the amorphous $\mathrm{NiP} / \mathrm{H} \beta$ catalyst showed good application potential as a non-noble metal catalyst. Calcination temperatures from 100 to $400{ }^{\circ} \mathrm{C}$ had almost no effect on pore properties. Meanwhile, the acid properties of the amorphous $\mathrm{NiP} / \mathrm{H} \beta$ catalyst were affected very little by calcination temperature. By increasing calcination temperature, the dispersion state of amorphous $\mathrm{NiP}$ became worse at $300{ }^{\circ} \mathrm{C}$, and then the structure of $\mathrm{NiP}$ changed from an amorphous structure into a crystalline structure at $400{ }^{\circ} \mathrm{C}$. In addition, the catalyst became more difficult to reduce with the increase in calcination temperature. Combined with the results of $n$-hexane isomerization catalyzed by different samples, the mechanism by which calcination temperature affects $n$-hexane isomerization over catalyst was revealed. It was shown that for the amorphous $\mathrm{NiP} / \mathrm{H} \beta$ catalyst, calcination temperature influences the catalytic performance mainly by affecting the dispersion degree and structure of active components.
\end{abstract}

Keywords: $\mathrm{n}$-hexane isomerization; amorphous $\mathrm{NiP} / \mathrm{H} \beta$ catalyst; calcination temperature; catalytic performance; influence mechanism

\section{Introduction}

In recent years, the isomerization of light alkanes has had an increasingly significant effect on improving the octane number of gasoline [1-5]. Due to the advantage of barely containing aromatics and olefins in its products, it is considered to be an environmentally friendly method in petroleum refining industry [6-9]. Recently, cleaner production has attracted more and more attention in various fields $[10,11]$. Now bifunctional metal/acid catalysts are extensively applied in the isomerization of light alkanes, and their active components are usually noble metals such as Pt and Pd [12-16]. Because of the existence of noble metals, the cost of catalysts is high, and their sulfur resistance is poor. Therefore, research into non-noble metal catalysts has attracted a lot of attention $[17,18]$.

However, many current non-noble metal catalysts have low catalytic activity in the isomerization of n-alkanes compared with noble metal catalysts [17-19]. Fortunately, our recent study proved that 
amorphous $\mathrm{NiP} / \mathrm{H} \beta$ catalysts exhibit a good catalytic function in the isomerization of light alkanes. It is well known that calcination temperature is a vitally important factor for the catalyst. For different kinds of catalysts, calcination temperatures exhibit different degrees of influence on the dispersion state and structure of the active components, pore structures, as well as their acid properties and other properties [20-22]. Meanwhile, the change of structure and other properties of catalysts would lead to changes in catalytic activity $[23,24]$, so it is significant to study the relationship between calcination temperatures and catalytic activity.

In consideration of the key questions mentioned above, a following research with respect to a novel amorphous $\mathrm{NiP} / \mathrm{H} \beta$ catalyst was conducted in this paper, so as to systematically clarify the influence of calcination temperature on the structural properties of the catalyst and its catalytic performance with respect to isomerization of n-alkanes, which has not been reported before. The research could provide very important guidance for the development of new non-noble metal catalysts.

\section{Materials and Methods}

\subsection{Catalyst Preparation}

Nickel chloride $\left(\mathrm{NiCl}_{2} \cdot 6 \mathrm{H}_{2} \mathrm{O}\right)$ and hypophosphorous acid $\left(\mathrm{H}_{3} \mathrm{PO}_{2}\right)$ were used as reactants to synthesize amorphous $\mathrm{NiP}$ active components via chemical reduction; further details are provided the Support information $[25,26]$.

The carrier was prepared via the mixture of $\mathrm{H} \beta$ molecular sieves and $\mathrm{Al}_{2} \mathrm{O}_{3} . \mathrm{H} \beta$ molecular sieves and $\mathrm{Al}_{2} \mathrm{O}_{3}$ were mixed as carrier according to a mass ratio of 3:1. A certain amount of amorphous NiP and carrier were fully mixed. After properly distilled water was added into the mixture, the products were extruded and dried at $70{ }^{\circ} \mathrm{C}$ for $2 \mathrm{~h}$. Afterwards, products were continually calcined under $\mathrm{N}_{2}$ at $100^{\circ} \mathrm{C}, 200^{\circ} \mathrm{C}, 300^{\circ} \mathrm{C}$ and $400^{\circ} \mathrm{C}$, respectively. Finally, amorphous $\mathrm{NiP} / \mathrm{H} \beta$ catalysts with different calcination temperatures were obtained.

\subsection{Characterization Methods and Catalytic Activity Measurements}

The analysis of the structures of different samples was performed by XRD. $\mathrm{N}_{2}$ adsorption-desorption isotherms were analyzed by the Quantachrome Autosorb-1MP volumetric adsorption analyzer. The acid properties of the catalyst surfaces were measured using Py-IR and $\mathrm{NH}_{3}$-TPD, respectively.

For Py-IR analysis, samples roasted at different temperatures were firstly kept at $100{ }^{\circ} \mathrm{C}$ for $2 \mathrm{~h}$ to remove water, and then they were exposed to gaseous pyridine at room temperature for $24 \mathrm{~h}$ under vacuum condition. After that, they were degassed for $2 \mathrm{~h}$ at $100{ }^{\circ} \mathrm{C}$ under vacuum condition to clear the pyridine of physical adsorption. Finally, the IR results were obtained at room temperature. For $\mathrm{NH}_{3}$-TPD analysis, samples were heated from $50{ }^{\circ} \mathrm{C}$ to $100^{\circ} \mathrm{C}$, and after that, the samples were kept at $100^{\circ} \mathrm{C}$ for $2 \mathrm{~h}$ under helium flow in order to remove water. Samples were saturated with ammonia after they had been cooled to $80^{\circ} \mathrm{C}$. Then they were purged by helium for $1 \mathrm{~h}$, after which they were heated to $700{ }^{\circ} \mathrm{C}$ under helium flow $(10 \mathrm{~mL} / \mathrm{min})$. The surface reduction properties of catalysts were characterized by $\mathrm{H}_{2}$-TPR and the crystalline temperatures of the samples were studied by DSC. SEM-mapping and TEM were used to study the dispersion state. TEM was also used to analyze the diameters of active components. These methods were conducted as described in the Support information.

The n-hexane isomerization performance was evaluated using a fixed-bed reactor. The reaction tube was a $550 \mathrm{~mm} \times 8 \mathrm{~mm}$ stainless steel tube. Before the test, $4.0 \mathrm{~g}$ of the catalyst was placed in the middle of the reaction tube, and both ends of the catalyst were tightly filled with quartz sand. The evaluation method for the $\mathrm{NiP} / \mathrm{H} \beta$ catalysts and the analysis method for the reaction products were performed as described in the Support information. 


\section{Results and Discussion}

\subsection{Characterization of Catalyst}

Nitrogen adsorption isotherms for $10 \mathrm{wt} \% \mathrm{NiP} / \mathrm{H} \beta$ calcined at different temperatures are displayed in Figure 1, which show similar configurations and belong to the type I+IV isotherm. The hysteresis loops of all of the samples belong to the type H4, suggesting that narrow slit-like pores are contained in them. The fast adsorption of nitrogen in the isotherms is generated by the micropore structures of $\mathrm{H} \beta$ [27].

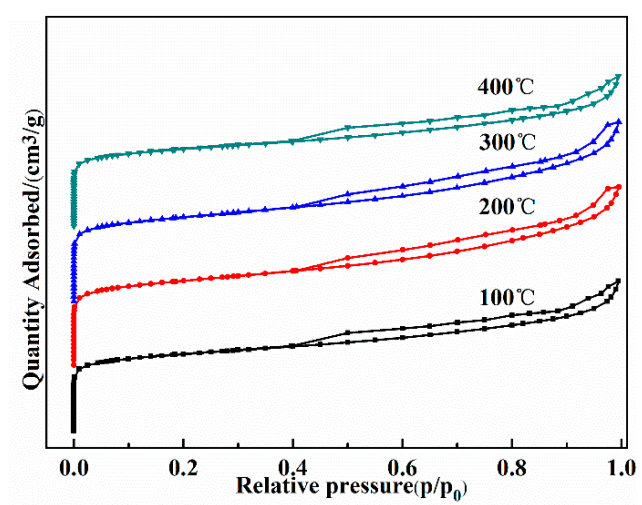

Figure 1. $\mathrm{N}_{2}$ adsorption-desorption isotherms for $10 \mathrm{wt} \% \mathrm{NiP} / \mathrm{H} \beta$ calcined at different temperatures.

Figure 2 shows the size distribution curves of the samples. It can be observed that samples calcined at different temperatures have similar narrow pore size distributions. At the same time, there are two sharp pore distribution peaks, and their pore diameters are between $0.6 \mathrm{~nm}$ and $1.3 \mathrm{~nm}$, respectively. The ranges of pore diameters are mainly from $0.5 \mathrm{~nm}$ to $0.7 \mathrm{~nm}$, which is attributed to the microporous range.
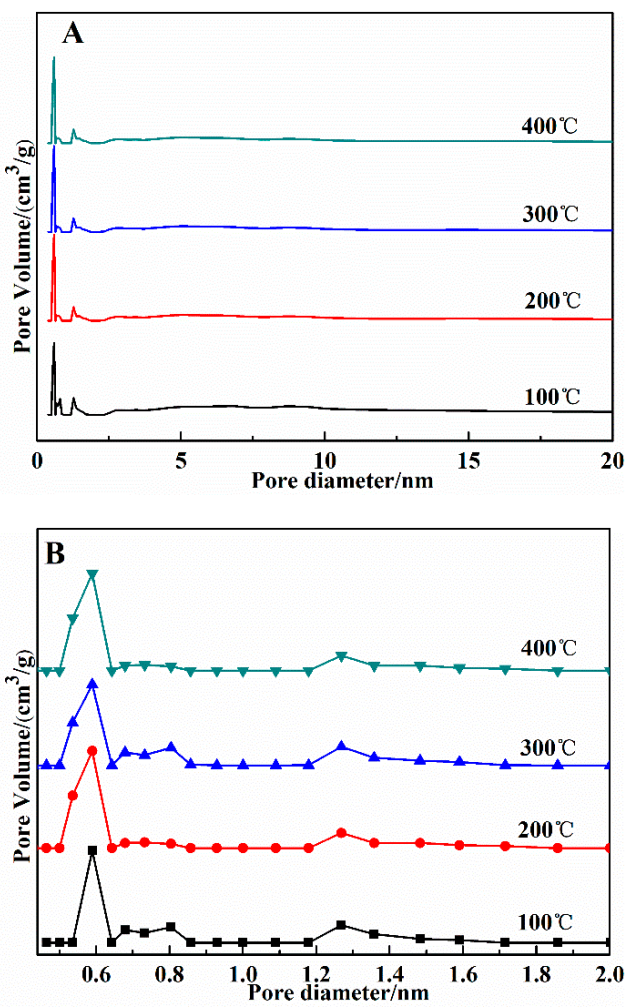

Figure 2. Pore size distribution curves for $10 \mathrm{wt} \% \mathrm{NiP} / \mathrm{H} \beta$ calcined at different temperatures. The range of pore diameter: (A) 0-35 $\mathrm{nm}$ and (B) 0-2 $\mathrm{nm}$ (magnification). 
To better illustrate how calcination temperature further influences catalysts, the textural properties of different samples are listed in Table 1.

Table 1. Textural properties of $10 \mathrm{wt} \% \mathrm{NiP} / \mathrm{H} \beta$ calcined at different temperatures.

\begin{tabular}{|c|c|c|c|}
\hline $\begin{array}{c}\text { Calcination } \\
\text { Temperatures } /{ }^{\circ} \mathrm{C}\end{array}$ & $\begin{array}{c}\text { BET } \\
\left(\mathrm{m}^{2} / \mathrm{g}\right)\end{array}$ & $\begin{array}{l}\text { Vmp. } \\
\left(\mathrm{cm}^{3} / \mathrm{g}\right)\end{array}$ & $\begin{array}{l}\mathrm{V}_{\mathrm{T}} \cdot{ }^{\mathrm{b}} \\
\left(\mathrm{cm}^{3} / \mathrm{g}\right)\end{array}$ \\
\hline 100 & 412.09 & 0.14 & 0.30 \\
\hline 200 & 411.10 & 0.14 & 0.30 \\
\hline 300 & 412.11 & 0.14 & 0.31 \\
\hline 400 & 411.29 & 0.13 & 0.30 \\
\hline
\end{tabular}

It could be clearly shown that the structural characteristics of samples remain almost the same when increasing roasting temperature. As shown by the above results (Figure 1, Figure 2 and Table 1), there is almost no change in the pore properties of catalysts when they are calcined from 100 to $400{ }^{\circ} \mathrm{C}$, and the pore structure of catalysts exhibits good stability in this temperature range. The reason for this lies in the fact that both $\mathrm{H} \beta$ and $\mathrm{Al}_{2} \mathrm{O}_{3}$ of the carrier have good thermal stability, and the pore structures of the samples remained intact below $400^{\circ} \mathrm{C}$.

The XRD results of the samples calcined from 100 to $400{ }^{\circ} \mathrm{C}$ are presented in Figure 3. For samples prepared at temperatures below $300{ }^{\circ} \mathrm{C}$, only diffraction signals of $\mathrm{H} \beta$ and $\mathrm{Al}_{2} \mathrm{O}_{3}$ could be observed in the catalysts [28], which could be ascribed to the fact that the NiP loadings of samples were relatively low, and in the meantime, the NiP nanoparticles of the samples at temperatures below $300{ }^{\circ} \mathrm{C}$ retained their amorphous structure. When the roasting temperature of $\mathrm{NiP} / \mathrm{H} \beta$ was further increased to $400{ }^{\circ} \mathrm{C}$, the XRD pattern of the sample began to obviously change. It can be seen that obvious peaks other than the peaks of carrier begin to appear at $2 \theta$ values of $44.6^{\circ}$ and $51.9^{\circ}$, implying the formation of more stable crystalline Ni on the catalyst surface at high temperature $[29,30]$.

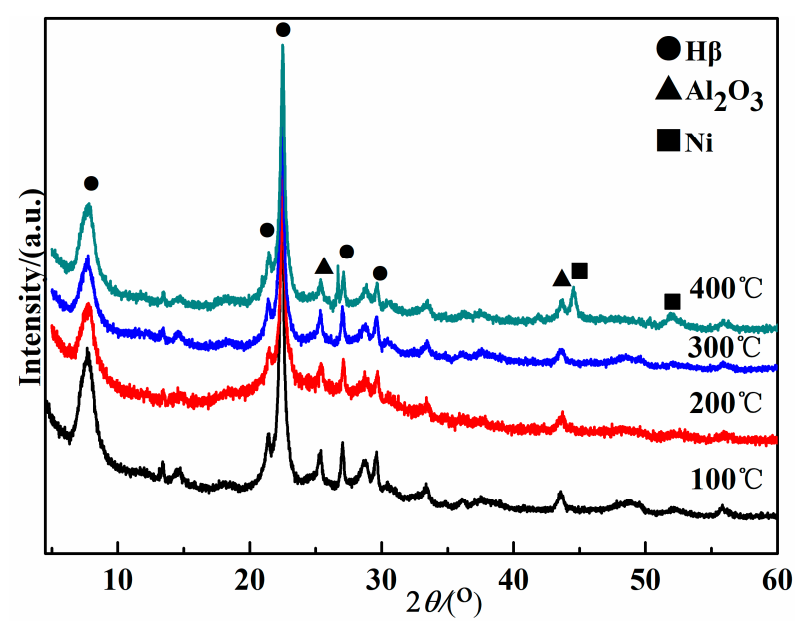

Figure 3. $\mathrm{XRD}$ patterns of $\mathrm{NiP} / \mathrm{H} \beta$ calcined at different temperatures.

Figure 4 shows the DSC results of the NiP nanoparticles when determining the crystalline temperature. There is an obvious endothermic peak below $200{ }^{\circ} \mathrm{C}$, which is mainly caused by the release of adsorbed water. As the heating temperature increases, two exothermic peaks located at about 360 and $460{ }^{\circ} \mathrm{C}$ can be observed, which are related to the crystallization of amorphous NiP nanoparticles. The exothermic peak at $360^{\circ} \mathrm{C}$ can probably be ascribed to the structural transformation of $\mathrm{NiP}$ active components from amorphous phase into crystalline $\mathrm{Ni}_{3} \mathrm{P}$ [31]. The exothermic peak at about $460^{\circ} \mathrm{C}$ is probably related to the transformation of metastable phase to stable Ni phase, a process that begins at about $440^{\circ} \mathrm{C}$. 


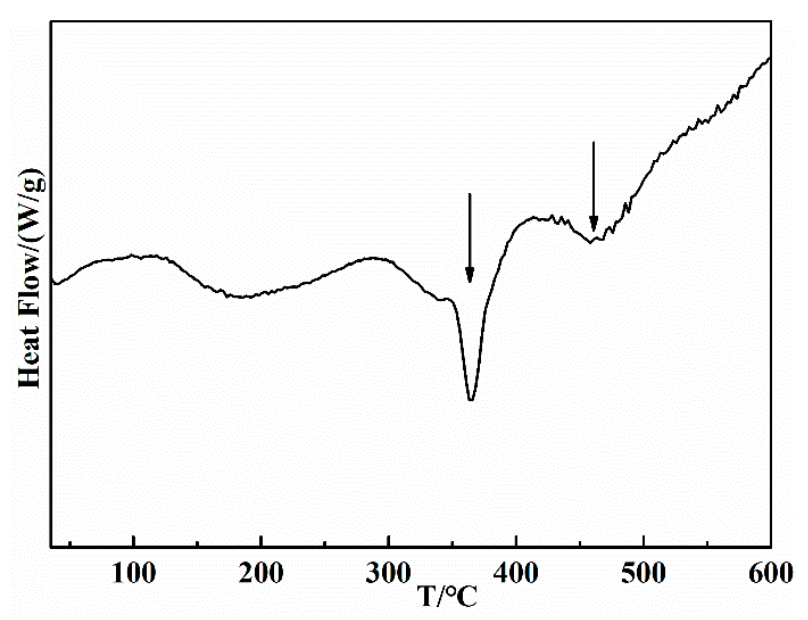

Figure 4. DSC curve of NiP.

As can be seen from Figure $5 \mathrm{~A}$, the TEM micrographs of amorphous $\mathrm{NiP} / \mathrm{H} \beta$ calcined at $200{ }^{\circ} \mathrm{C}$ show that $\mathrm{NiP}$ nanoparticles have spherical or chainlike structures, with average diameters ranging from 50 to $100 \mathrm{~nm}$. For $\mathrm{NiP} / \mathrm{H} \beta$ calcined at $200{ }^{\circ} \mathrm{C}$, NiP nanoparticles supported on carrier show good dispersion. When the calcination temperature was $300^{\circ} \mathrm{C}$, there were no obvious changes in the average diameters and shapes of NiP nanoparticles (Figure 5B), implying that the active components still retain a good amorphous structure. However, compared with samples calcined at temperatures below $200{ }^{\circ} \mathrm{C}$, the degree of dispersion of active components becomes worse when the temperature reaches $300{ }^{\circ} \mathrm{C}$. With the increase in calcination temperature to $400{ }^{\circ} \mathrm{C}$ (Figure 5C), the sizes of the NiP nanoparticles decreased rapidly, and the state of active components changes into a crystalline state. Owing to the decrease in the size of the NiP nanoparticles after crystallization, the degree of dispersion of the NiP nanoparticles improves instead. Moreover, the SAED picture of $\mathrm{NiP} / \mathrm{H} \beta$ calcined at $400{ }^{\circ} \mathrm{C}$ is displayed in Figure 5D to further determine the structure of active components. Figure 5D shows that some bright white spots exist in the SAED picture, sufficiently confirming that the structure of the $\mathrm{NiP}$ active components has partly changed from an amorphous state into a crystalline state. The TEM results are basically confirmed by the XRD and DSC results.
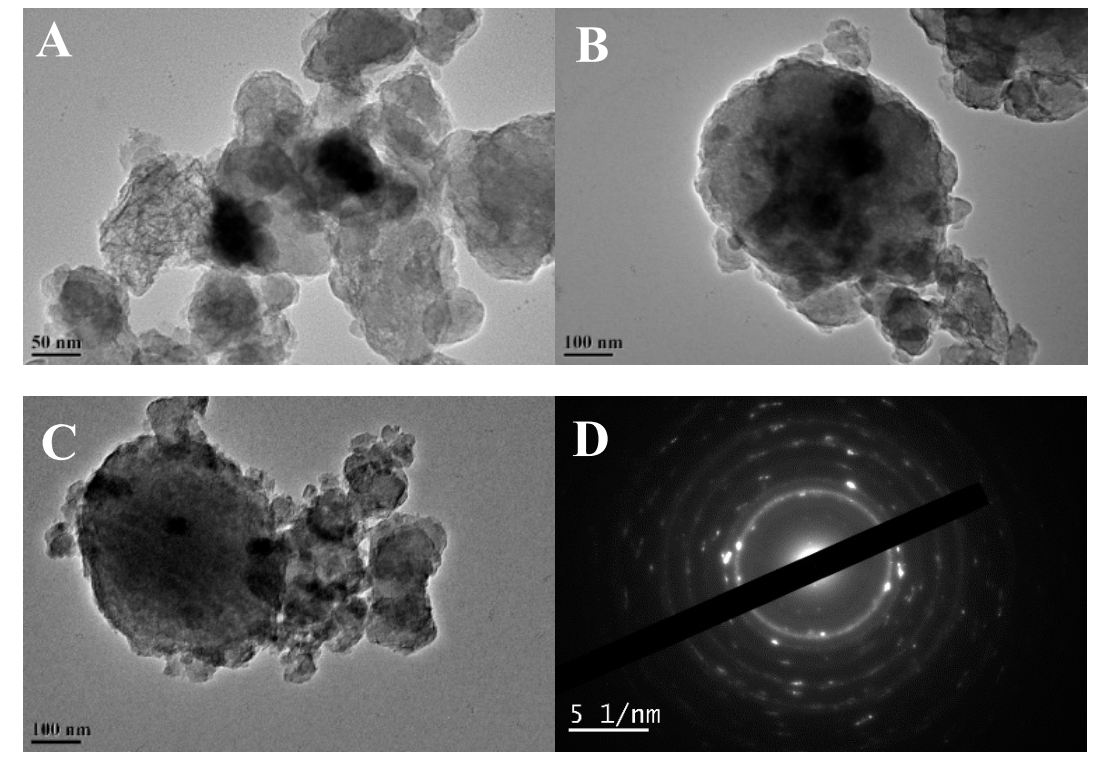

Figure 5. TEM micrographs of the samples: (A) $\mathrm{NiP} / \mathrm{H} \beta$ calcined at $200{ }^{\circ} \mathrm{C},(\mathbf{B}) \mathrm{NiP} / \mathrm{H} \beta$ calcined at $300{ }^{\circ} \mathrm{C},(\mathrm{C}) \mathrm{NiP} / \mathrm{H} \beta$ calcined at $400{ }^{\circ} \mathrm{C}$ and (D) SAED picture of $\mathrm{NiP} / \mathrm{H} \beta$ calcined at $400{ }^{\circ} \mathrm{C}$. 
Figure 6 shows the SEM-mappings of the catalyst, containing the dispersion of $\mathrm{P}$ and $\mathrm{Ni}$, respectively. For the catalyst calcined at $200^{\circ} \mathrm{C}$, the amorphous NiP nanoparticles are dispersed well, and the results are coincident with the XRD (Figure 3) and TEM results (Figure 5).

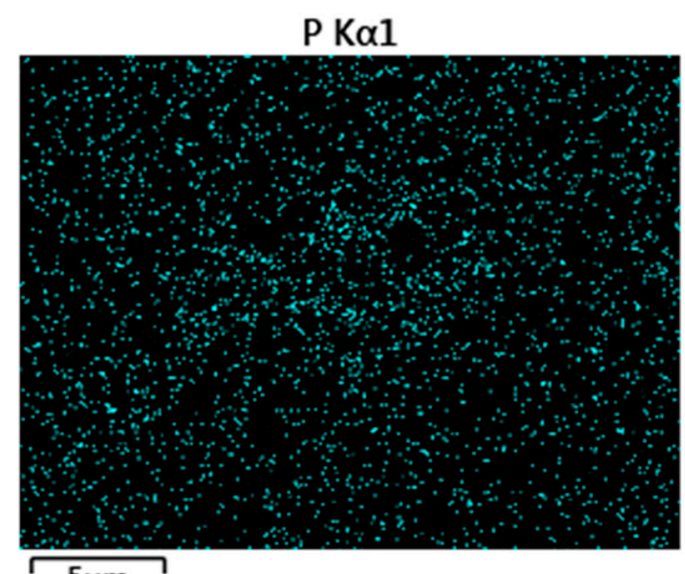

$5 \mu \mathrm{m}$

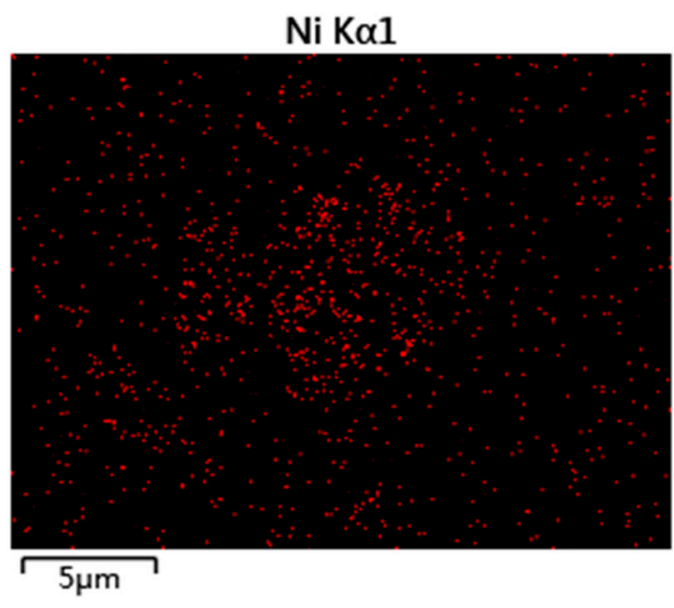

$5 \mu \mathrm{m}$

Figure 6. SEM-mappings of $\mathrm{NiP} / \mathrm{H} \beta$ calcined at $200^{\circ} \mathrm{C}$.

Absorbance peaks characteristic of hydrogen-bound pyridine (H), Brønsted (B), weak Lewis (WL), and strong Lewis (SL) sites are indicated.

The Py-IR spectra of catalysts roasted at different temperatures are shown in Figure 7. The bands generated by pyridine adsorbed on Bronsted (B) and Lewis (L) acid sites are located at approximately 1540 and $1450 \mathrm{~cm}^{-1}$, respectively. On the whole, there is almost no difference in the number of Brønsted and Lewis acid sites for samples roasted at different temperatures [32,33]. The bands appearing at around 1610 and $1575 \mathrm{~cm}^{-1}$ suggest the existence of strong and weak Lewis acid sites, respectively [34]. The numbers of strong Lewis (SL) acid sites in samples calcined at $100{ }^{\circ} \mathrm{C}, 200{ }^{\circ} \mathrm{C}$ and $300{ }^{\circ} \mathrm{C}$ are almost the same [35]; however, the number of SL acid sites in the sample roasted at $400{ }^{\circ} \mathrm{C}$ is slightly decreased in comparison with the other samples. The reason for this can be attributed to the fact that the existence of SL acid sites is closely associated with the unsaturated nickel atoms of amorphous NiP nanoparticles. When the calcination temperature is increased to $400{ }^{\circ} \mathrm{C}, \mathrm{NiP}$ nanoparticles gradually transform from their amorphous state into a crystalline Ni phase (Figure 3), decreasing the amount of unsaturated $\mathrm{Ni}$ atoms and ultimately leading to a decrease in the number of SL acid sites.

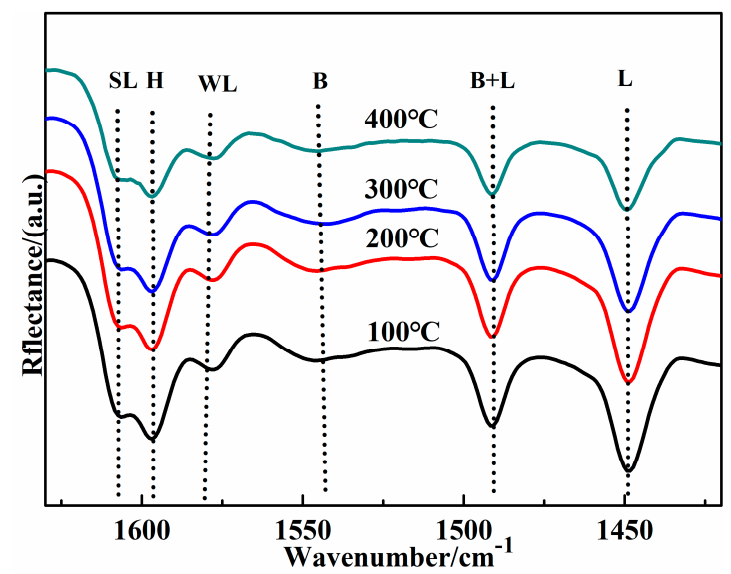

Figure 7. Py-IR spectra of $10 \mathrm{wt} \% \mathrm{NiP} / \mathrm{H} \beta$ calcined at different temperatures.

The $\mathrm{NH}_{3}$-TPD profiles of samples calcined at different temperatures are displayed in Figure 8. It can be seen that there is almost no difference in the $\mathrm{NH}_{3}$-TPD patterns for the different samples. 
In the range of $80-650^{\circ} \mathrm{C}$, a broad desorption curve with a desorption peak at about $170{ }^{\circ} \mathrm{C}$ appears for all samples, and another desorption peak appears at about $390{ }^{\circ} \mathrm{C}$, suggesting that there are two types of acid site existing on the sample surfaces.

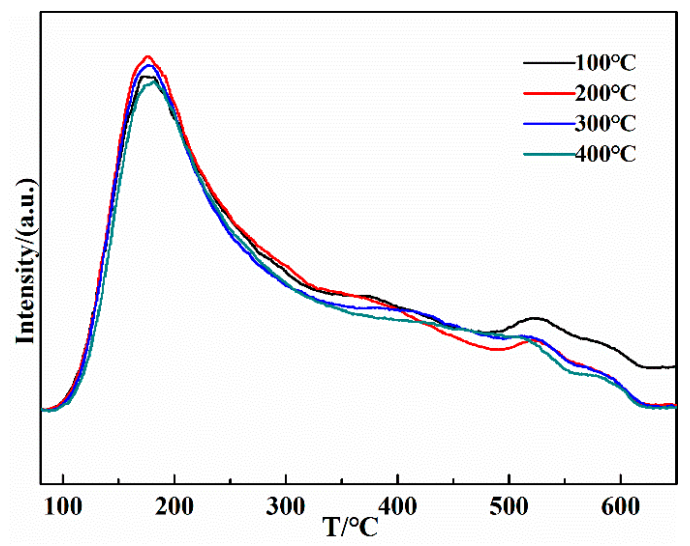

Figure 8. $\mathrm{NH}_{3}$-TPD profiles of $10 \mathrm{wt} \% \mathrm{NiP} / \mathrm{H} \beta$ calcined at different temperatures.

The desorption peak curves below $300{ }^{\circ} \mathrm{C}$ are closely related with the weak acid sites, and those above $300{ }^{\circ} \mathrm{C}$ imply that there are also SL sites on the catalysts $[36,37]$. Nevertheless, the peak located at about $500{ }^{\circ} \mathrm{C}$ becomes very weak for the sample calcined at a temperature of $400{ }^{\circ} \mathrm{C}$, due to the fact that the number of unsaturated $\mathrm{Ni}$ atoms decreases as the decomposition of most of the amorphous $\mathrm{NiP}$ nanoparticles into stable $\mathrm{Ni}$ (Figures 3 and 4) [38]. It can be observed that the $\mathrm{NH}_{3}-\mathrm{TPD}$ results are consistent with the results of Py-IR spectra (Figure 7), indicating that when the calcination temperature was $400{ }^{\circ} \mathrm{C}$, the decrease of strong acid sites was mainly strong Lewis sites. Overall, the above results reveal that the acid properties of amorphous $\mathrm{NiP} / \mathrm{H} \beta$ catalysts were minimally affected by calcination temperature, having good stability at temperatures ranging from $100{ }^{\circ} \mathrm{C}$ to $400{ }^{\circ} \mathrm{C}$.

The reduction profiles of different samples are presented in Figure 9. Two distinct reduction peaks can be observed in the TPR curves of all of the samples, implying that there are two reducible species appearing in the reduction process under the $\mathrm{H}_{2}$ atmosphere. The low-temperature peak is probably generated by the reduction of the amorphous $\mathrm{NiP}$ nanoparticles into $\mathrm{Ni}_{3} \mathrm{P}$; meanwhile, the high-temperature peak can be attributed to the reduction of $\mathrm{Ni}_{3} \mathrm{P}$ into $\mathrm{Ni}$ on the catalyst $[31,39]$. With the increase in calcination temperature for samples from $100{ }^{\circ} \mathrm{C}$ to $400{ }^{\circ} \mathrm{C}$, the low-temperature reduction peak gradually increases from $330{ }^{\circ} \mathrm{C}$ to $400{ }^{\circ} \mathrm{C}$, and the high-temperature peak gradually increases from $450{ }^{\circ} \mathrm{C}$ to $600^{\circ} \mathrm{C}$. It can be observed that catalysts are more difficult to reduce with the increase in calcination temperature, and the increased difficulty in reduction could be related to the stronger interaction of $\mathrm{NiP}$ nanoparticles and $\mathrm{Ni}_{3} \mathrm{P}$ reducible species with the carrier.

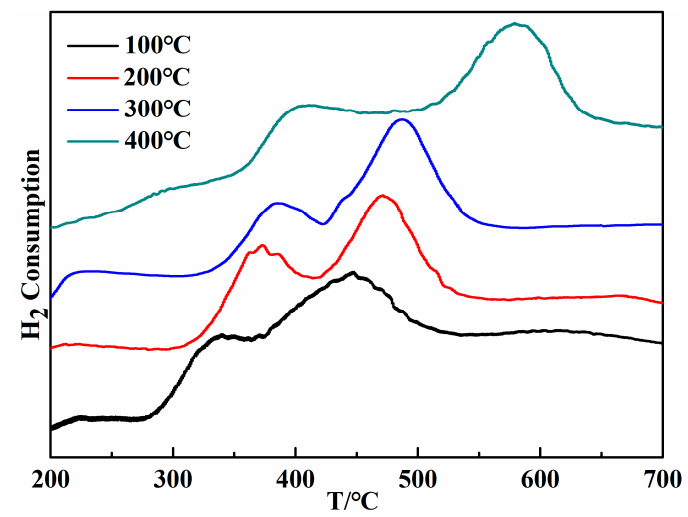

Figure 9. The TPR profiles of $10 \mathrm{wt} \% \mathrm{NiP} / \mathrm{H} \beta$ calcined at different temperatures. 


\subsection{Catalytic Activity and Influence Mechanism}

Reaction conditions: $\mathrm{T}=290^{\circ} \mathrm{C}, \mathrm{P}=2.0 \mathrm{MPa}$, WHSV $=1.0 \mathrm{~h}^{-1}, \mathrm{H}_{2}$-to-n-hexane molar ratio $=4.0$, Reaction time $=4 \mathrm{~h}$.

The effect of calcination temperatures on n-hexane isomerization is displayed in Figure 10, showing the n-hexane conversion and the yield of isomerization products, respectively. To reduce the experimental errors of catalytic testing, the data were all tested three times, and then averaged.
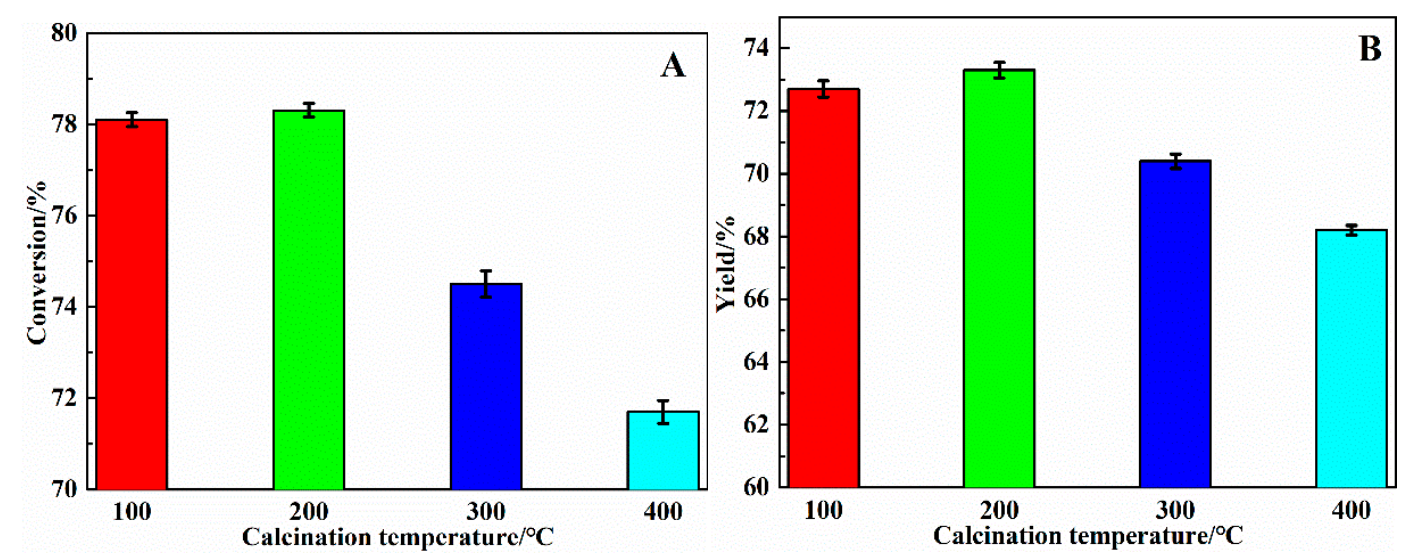

Figure 10. Effect of calcination temperatures on (A) the n-hexane conversion, and (B) the yield of iso-alkanes (i- $\mathrm{C}_{5}$ and $\left.\mathrm{i}-\mathrm{C}_{6}\right)$.

The results show that n-hexane conversion and yield of isomerization products have the same variation tendency, and that they first increase and then subsequently decrease with increasing calcination temperatures of the samples. When calcination temperatures were increased to $200{ }^{\circ} \mathrm{C}$, both the n-hexane conversion and yield of isomerization products simultaneously reached their maximum. The catalytic performance of the sample calcined at $100{ }^{\circ} \mathrm{C}$ was slightly reduced in comparison with the sample calcined at $200{ }^{\circ} \mathrm{C}$.

To further confirm the effect of calcination temperatures on catalytic activity, the product distributions of $10 \mathrm{wt} \% \mathrm{NiP} / \mathrm{H} \beta$ calcined at different temperatures are listed in Table 2. As shown in Table 2, both the n-hexane conversion and yield of iso-alkanes (i- $\mathrm{C}_{6}$ and $\mathrm{i}-\mathrm{C}_{5-6}$ ) first increase and then decrease with the increase in calcination temperature from $100{ }^{\circ} \mathrm{C}$ to $400{ }^{\circ} \mathrm{C}$. The catalyst calcined at $200{ }^{\circ} \mathrm{C}$ has the best catalytic activity. Especially with respect to the high-octane components 2,2-dimethyl butane and 2,3-dimethyl butane, their yield reached up to $18.2 \%$ when the temperature is $200{ }^{\circ} \mathrm{C}$. Meanwhile, for crystalline Ni/SAPO- 11 catalyst, the n-hexane conversion was about $73 \%$ and the yield of high-octane components 2,2-dimethyl butane and 2,3-dimethyl butane was about $5 \%$ [40]. Additionally, for noble metal Pt/HY catalyst, the n-hexane conversion was about $74 \%$, and the yield of high-octane components 2,2-dimethyl butane and 2,3-dimethyl butane was less than $17 \%$ [41]. The comparison results convincingly imply that the amorphous $\mathrm{NiP} / \mathrm{H} \beta$ catalyst has good application prospects. 
Table 2. The product distribution of $10 \mathrm{wt} \% \mathrm{NiP} / \mathrm{H} \beta$ calcined at different temperatures.

\begin{tabular}{ccccc}
\hline \multirow{2}{*}{ Compenents } & \multicolumn{4}{c}{ Wt. \% of $\mathbf{n - H e x a n e}$ Converted to Different Components } \\
\cline { 2 - 5 } & $\mathbf{1 0 0}{ }^{\circ} \mathbf{C}$ & $\mathbf{2 0 0}{ }^{\circ} \mathbf{C}$ & $\mathbf{3 0 0}^{\circ} \mathbf{C}$ & $\mathbf{4 0 0}{ }^{\circ} \mathbf{C}$ \\
\hline$<\mathrm{C}_{4}$ & 1.0 & 0.9 & 0.8 & 0.7 \\
$\mathrm{iC}_{4}$ & 0.7 & 0.6 & 0.5 & 0.3 \\
$\mathrm{nC}_{4}$ & 1.8 & 1.7 & 1.3 & 1.1 \\
$\mathrm{iC}_{5}$ & 2.5 & 1.5 & 0.9 & 0.3 \\
$\mathrm{nC}_{5}$ & 1.9 & 1.8 & 1.5 & 1.4 \\
2,2-dimethyl butane & 8.1 & 10.1 & 6.3 & 4.7 \\
2,3-dimethyl butane & 8.2 & 8.1 & 8.4 & 8.5 \\
2- methyl pentane & 32.2 & 31.5 & 32.2 & 32.3 \\
3- methyl pentane & 21.7 & 22.1 & 22.6 & 22.4 \\
i-C & 70.2 & 71.8 & 69.5 & 67.9 \\
i-C $_{5-6}$ & 72.7 & 73.3 & 70.4 & 68.2 \\
nC $_{6}$ & 21.9 & 21.7 & 25.5 & 28.3 \\
Conversion & 78.1 & 78.3 & 74.5 & 71.7 \\
\hline
\end{tabular}

Reaction conditions: $\mathrm{T}=290^{\circ} \mathrm{C}, \mathrm{P}=2.0 \mathrm{MPa}, \mathrm{WHSV}=1.0 \mathrm{~h}^{-1}, \mathrm{H}_{2}$-to-n-hexane molar ratio $=4.0$, Reaction time $=4 \mathrm{~h}$.

The results for Py-IR (Figure 7) and $\mathrm{NH}_{3}$-TPD (Figure 8) reveal that calcination temperature has no significant impact on acid properties. At the same time, the results for the textural properties of the samples (Table 1) show that calcination temperature has almost no influence on pore properties. Combined with the results of $n$-hexane isomerization for samples with different calcination temperatures (Figure 10), the conclusion could be drawn that the difference in catalytic performance is not caused by the changes in acid properties and pore properties for amorphous $\mathrm{NiP} / \mathrm{H} \beta$ catalyst. With respect to $\mathrm{NiP}$ nanoparticles as the active components of alkane isomerization catalysts for hydrogenation and dehydrogenation, their dispersion state and structure in the catalyst have a significant influence on their catalytic performance. As can be seen from Figures 3 and 5, for the catalysts calcined at $100^{\circ} \mathrm{C}$ and $200^{\circ} \mathrm{C}$, the NiP nanoparticles could maintain their amorphous state and their dispersion properties were good. At the same time, their catalytic activities were good, and were nearly the same. By increasing calcination temperature from $200{ }^{\circ} \mathrm{C}$ to $300^{\circ} \mathrm{C}$, although $\mathrm{NiP}$ nanoparticles maintained their amorphous state, the degree of dispersion decreased slightly (Figure 5). These result suggest that the reduction of the reactivity for the sample calcined at $300^{\circ} \mathrm{C}$ was probably due to the decreased dispersion properties of the active components. When the calcination temperature was increased to $400{ }^{\circ} \mathrm{C}$, crystalline Ni began to be observed on the sample surface (Figure 3) and the catalytic activity continued to decrease (Figure 10).

Based on the results described above, the mechanism by which calcination temperature influences the amorphous $\mathrm{NiP} / \mathrm{H} \beta$ catalyst is studied and proposed (Scheme 1). In the process of the catalytic reaction, $\mathrm{NiP}$ nanoparticles act as hydrogenation-dehydrogenation centers. $\mathrm{H} \beta$ zeolites act as acid centers and provide the reaction space. For the amorphous $\mathrm{NiP} / \mathrm{H} \beta$ catalyst, calcination temperature has no significant impact on pore properties and acid properties, indicating that the acid and pore properties are not key factors that result in changes of catalytic activity. However, calcination temperature could significantly affect the dispersion state and structure of active components, which may first transform from amorphous $\mathrm{NiP}$ into crystalline $\mathrm{Ni}_{3} \mathrm{P}$ and then further convert into stable crystalline $\mathrm{Ni}$. In the process of increasing the calcination temperature, their dispersion degree first became worse, leading to a decrease in the uniformity of the metal sites. In addition, the state of the active components then transformed from an amorphous structure into a crystalline structure, leading to a decrease of the disorder degree of the active components. Based on the above reasons, the catalytic performance of $\mathrm{n}$-hexane isomerization is ultimately influenced. 


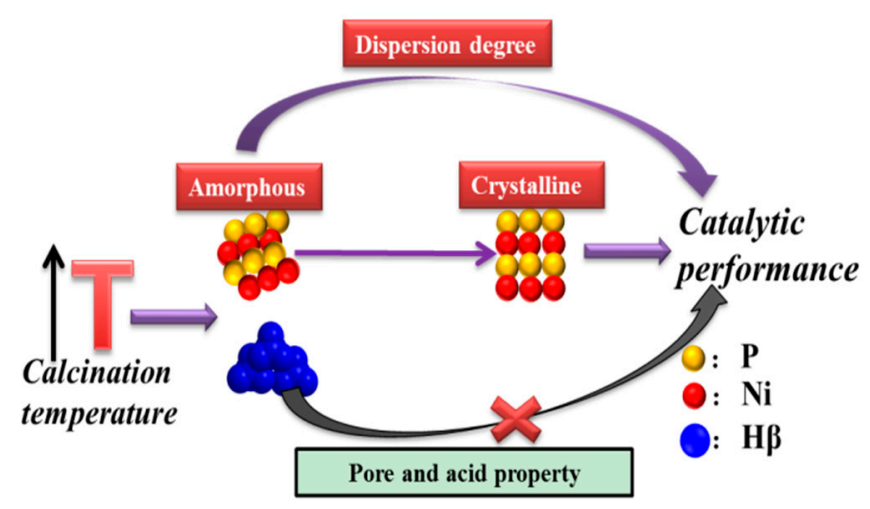

Scheme 1. Mechanism of the effect of calcination temperature on catalytic performance for amorphous $\mathrm{NiP} / \mathrm{H} \beta$ catalyst.

The stability of catalysts is an important aspect for application, and their long-reaction activity was studied. The results are shown in Figure S1 (Support information). It can be clearly seen that $n-\mathrm{C}_{6}$ conversion remains above $75 \%$ after $3 \mathrm{~h}$, with selectivity to isomers $\left(\mathrm{C}_{5}-\mathrm{C}_{6}\right)$ of above $90 \%$ and yield of isomers above $72 \%$. The catalyst could maintain good catalytic stability for at least $300 \mathrm{~h}$, implying that it has good catalytic stability.

\section{Conclusions}

For the amorphous $\mathrm{NiP} / \mathrm{H} \beta$ catalyst, calcination temperatures from 100 to $400{ }^{\circ} \mathrm{C}$ have almost no effect on pore properties, due to the fact that $\mathrm{H} \beta$ and $\mathrm{Al}_{2} \mathrm{O}_{3}$ have good thermal stability in carrier. Meanwhile, the acid properties of amorphous $\mathrm{NiP} / \mathrm{H} \beta$ catalysts were minimally affected by calcination temperature, exhibiting good stability in the temperature range from $100{ }^{\circ} \mathrm{C}$ to $400{ }^{\circ} \mathrm{C}$. However, the amount of SL acid sites on the sample calcined at $400{ }^{\circ} \mathrm{C}$ was slightly reduced compared with the other samples, on account of the reduction of amorphous NiP nanoparticles. Moreover, by increasing the roasting temperature, catalysts were more difficult to reduce. As calcination temperature increases, the dispersion state of the amorphous $\mathrm{NiP}$ becomes worse at $300{ }^{\circ} \mathrm{C}$, while the structure of the amorphous $\mathrm{NiP}$ as an active component subsequently gradually changes into crystalline $\mathrm{Ni}_{3} \mathrm{P}$ and $\mathrm{Ni}$. As calcination temperature increases, the catalytic activity of the samples first increased, and then decreased. When calcination temperature was $200{ }^{\circ} \mathrm{C}$, the yield of the high-octane components 2,2-dimethyl butane and 2,3-dimethyl butane reached up to $18.2 \%$.

Combined with the catalytic activity of $n$-hexane isomerization catalyzed by different samples, the influence mechanism is revealed. For amorphous $\mathrm{NiP} / \mathrm{H} \beta$ catalyst, calcination temperature influences the catalytic activity of n-hexane isomerization mainly by affecting the dispersion state and the structure of the active components.

Supplementary Materials: The following are available online at http://www.mdpi.com/2073-4344/10/7/811/s1.

Author Contributions: Conceptualization, J.C. and D.X.; methodology, J.C.; validation, J.C., D.X.; formal analysis, L.Z., Y.X.; resources, J.C.; data curation, J.C.; writing-original draft preparation, J.C.; writing-review and editing, J.C.; supervision, J.C. and D.X.; project administration, J.C.; funding acquisition, J.C., L.Z. and D.X. All authors have read and agreed to the published version of the manuscript.

Funding: This research was funded by the National Natural Science Foundation of China (Grant U1662115) and Shandong Province Natural Science Foundation (ZR2019MB057).

Conflicts of Interest: The authors declare no conflict of interest. 


\section{References}

1. Setiabudi, H.D.; Jalil, A.A.; Triwahyono, S.; Kamarudin, N.H.N.; Jusoh, R. Ir/Pt-HZSM5 for n-pentane isomerization: Effect of $\mathrm{Si} / \mathrm{Al}$ ratio and reaction optimization by response surface methodology. Chem. Eng. J. 2013, 217, 300-309. [CrossRef]

2. Chica, A.; Corma, A. Hydroisomerization of Pentane, Hexane, and Heptane for improving the Octane Number of Gasoline. J. Catal. 1999, 187, 167-176. [CrossRef]

3. Arribas, M.A.; Márquez, F.; Martínez, A. Activity, Selectivity, and Sulfur Resistance of $\mathrm{Pt} / \mathrm{WO}_{\mathrm{X}}-\mathrm{ZrO}_{2}$ and $\mathrm{Pt} /$ Beta Catalysts for the Simultaneous Hydroisomerization of $\mathrm{n}$-Heptane and Hydrogenation of Benzene. J. Catal. 2000, 190, 309-319. [CrossRef]

4. Tamizhdurai, P.; Ramesh, A.; Santhana Krishnan, P.; Narayanan, S.; Shanthi, K.; Sivasanker, S. Effect of acidity and porosity changes of dealuminated mordenite on n-pentane, n-hexane and light naphtha isomerization. Microporous Mesoporous Mater. 2019, 287, 192-202. [CrossRef]

5. Yang, L.; Wang, W.; Song, X.M.; Bai, X.F.; Feng, Z.L.; Liu, T.; Wu, W. The hydroisomerization of n-decane over Pd/SAPO-11 bifunctional catalysts: The effects of templates on characteristics and catalytic performances. Fuel Process. Technol. 2019, 190, 13-20. [CrossRef]

6. Setiabudi, H.D.; Jalil, A.A.; Triwahyono, S. Ir/Pt-HZSM5 for n-pentane isomerization: Effect of iridium loading on the properties and catalytic activity. J. Catal. 2012, 294, 128-135. [CrossRef]

7. Zhang, R.; Meng, X.H.; Liu, Z.C.; Meng, J.Y.; Xu, C.M. Isomerization of n-Pentane Catalyzed by Acidic Chloroaluminate Ionic Liquids. Ind. Eng. Chem. Res. 2008, 47, 8205-8210. [CrossRef]

8. Gao, L.; Shi, Z.Y.; Jerome Etim, U.; Wu, P.P.; Xing, W.; Zhang, Y.; Bai, P.; Yan, Z.F. Superior catalytic performance of micro-mesoporous Beta-SBA-15 composite with a high indexed isomerization factor in hydroisomerization of n-heptane. Fuel 2019, 252, 653-665. [CrossRef]

9. Rizescu, C.; Cojocaru, B.; Thanh Hien, N.T.; Huyenb, P.T.; Parvulescu, V.I. Synergistic B-Al interaction in SBA-15 affording an enhanced activity for the hydro-isomerization of heptane over PteBeAl-SBA-15 catalysts. Microporous Mesoporous Mater. 2019, 281, 142-147. [CrossRef]

10. Bao, Q.; Nie, W.; Liu, C.Q.; Zhang, H.H.; Wang, H.K.; Jin, H.; Yan, J.Y.; Liu, Q. The preparation of a novel hydrogel based on crosslinked polymers for suppressing coal dusts. J. Clean. Prod. 2020, 249,1-12. [CrossRef]

11. Yuan, M.Y.; Nie, W.; Zhou, W.W.; Yan, J.Y.; Bao, Q.; Guo, C.J.; Tong, P.; Zhang, H.H.; Guo, L.D. Determining the effect of the non-ionic surfactant AEO9 on lignite adsorption and wetting via molecular dynamics (MD) simulation and experiment comparisons. Fuel 2020, 278, 1-13. [CrossRef]

12. Roldán, R.; Beale, A.M.; Sánchez-Sánchez, M.; Romero-Salguero, F.J.; Jiménez-Sanchidrián, C.; Gómez, J.P.; Sankar, G. Effect of the impregnation order on the nature of metal particles of bi-functional Pt/Pd-supported zeolite beta materials and on their catalytic activity for the hydroisomerization of alkanes. J. Catal. 2008, 254, 12-26.

13. Li, H.; Li, M.; Chu, Y.; Nie, H. Influence of different modified zeolite on skeletal isomerization of n-hexene in the presence of hydrogen. Microporous Mesoporous Mater. 2009, 117, 635-639. [CrossRef]

14. Santiesteban, J.G.; Calabro, D.C.; Chang, C.D.; Vartuli, J.C.; Fiebig, T.J.; Bastian, R.D. The role of platinum in hexane isomerization over $\mathrm{Pt} / \mathrm{FeO}_{\mathrm{y}} / \mathrm{WO}_{\mathrm{x}} / \mathrm{ZrO}_{2}$. J. Catal. 2001, 202, 25-33. [CrossRef]

15. Duchet, J.C.; Guillaume, D.; Monnier, A.; Dujardin, C.; Gilson, J.P.; Gestel, J.V.; Szabo, G.; Nascimento, P. Isomerization of n-hexane over sulfated zirconia: Influence of hydrogen and platinum. J. Catal. 2001, 198, 328-337. [CrossRef]

16. Triwahyono, S.; Jalil, A.A.; Izan, S.M.; Jamari, N.S.; Fatah, A.A. Isomerization of linear $\mathrm{C}_{5}-\mathrm{C}_{7}$ over Pt loaded on protonated fibrous silica@Y zeolite (Pt/HSi@Y). J. Energy Chem. 2019, 37, 163-171. [CrossRef]

17. Masalska, A.; Grzechowiak, J.R.; Jaroszewska, K. Effect of metal-support interactions in Ni/ZSM-5 $+\mathrm{Al}_{2} \mathrm{O}_{3}$ catalysts on the transformation of n-paraffins. Top. Catal. 2013, 56, 981-994. [CrossRef]

18. Ohno, T.; Li, Z.; Sakai, N.; Sakagami, H.; Takahashi, N.; Matsuda, T. Heptane isomerization over molybdenum oxides obtained by $\mathrm{H}_{2}$ reduction of $\mathrm{H}_{x} \mathrm{MoO}_{3}$ with different hydrogen contents. Appl. Catal. A Gen. 2010, 389, 52-59. [CrossRef]

19. Goguet, A.; Shekhtman, S.; Cavallaro, F.; Hardacre, C.; Meunier, F.C. Effect of the carburization of $\mathrm{MoO}_{3}$-based catalysts on the activity for butane hydroisomerization. Appl. Catal. A Gen. 2018, 344, 30-35. [CrossRef] 
20. Belandria, L.; Marín-Astorg, N.; García, E.; Sos, E.; Aguirre, F.; Villarroel, M.; Uzcátegui, A. Catalytic activity of $\mathrm{Pt}$ and $\mathrm{Pd}$ catalysts supported on HWP/HMS in the selective hydroisomerization of n-pentane. Effect of reaction temperature. Catal. Today 2011, 172, 2-7. [CrossRef]

21. Song, Y.Q.; Tian, J.; Ye, Y.R.; Jin, Y.Q.; Zhou, X.L.; Wang, J.; Xu, L.Y. Effects of calcination temperature and water-washing treatment on $\mathrm{n}$-hexane hydroisomerization behavior of Pt-promoted sulfated zirconia based catalysts. Catal. Today 2013, 212, 108-114. [CrossRef]

22. Zhou, X.L.; Yu, G.X.; Tang, C.; Li, C.L.; Wang, J.A.; Novaro, O.; Llanos, M.E.; Cortés-Jácome, M.A. On the Role of Calcination Temperature in $\mathrm{Pt}_{-} \mathrm{SO}_{4}{ }^{2-} / \mathrm{ZrO}_{2}-\mathrm{Al}_{2} \mathrm{O}_{3}$ Preparation and Catalytic Behaviors During the n-Hexane Hydroisomerization. Catal. Lett. 2008, 124, 277-283. [CrossRef]

23. Zhang, M.; Chen, L.M.; Yao, S.Y.; Long, Y.M.; Li, W.F.; Wang, Z.S. Effect of calcination temperature on the photocatalytic activity of $\mathrm{CaSb}_{2} \mathrm{O}_{6}$ nanoparticles prepared by co-precipitation method. Catal. Commun. 2014, 48, 29-32. [CrossRef]

24. Wang, G.W.; Wu, W.L.; Zhu, X.L.; Sun, Y.N.; Li, C.Y.; Shan, H.H. Effect of calcination temperature on isobutane dehydrogenation over $\mathrm{Mo} / \mathrm{MgAl}_{2} \mathrm{O}_{4}$ catalysts. Catal. Commun. 2014, 56, 119-122. [CrossRef]

25. Ma, Y.F.; Zhang, M.H.; Li, W.; Zhang, B.G.; Tao, K.Y. Preparation and catalytic activity of NiP amorphous alloy with high surface area. Chin. J. Catal. 2004, 25, 973-978.

26. Ma, Y.F.; Li, W.; Zhang, M.H.; Zhang, B.G.; Tao, K.Y. New method of preparing NiP and NiPB amorphous alloys using nickel hypophosphite as reactant. Acta Phys.-Chim. Sin. 2002, 18, 938-942.

27. Deng, H.X.; Grunder, S.; Cordova, K.E.; Valente, C.; Furukawa, H.; Hmadeh, M.; Gándara, F.; Whalley, A.C. Large-pore apertures in a series of metal-organic frameworks. Science 2012, 336, 1018-1023. [CrossRef] [PubMed]

28. Wan, G.F.; Duan, A.J.; Zhang, Y.; Zhao, Z.; Jiang, G.Y.; Zhang, D.Q.; Gao, Z.Y.; Liu, J. Hydrodesulfurization of Fluidized Catalytic Cracking Diesel Oil over NiW/AMB Catalysts Containing H-Type $\beta$-Zeolite in Situ Synthesized from Kaolin Material. Energy Fuels 2019, 23, 3846-3852. [CrossRef]

29. Kapfenberger, C.; Hofmann, K.; Albert, B. Room-temperature synthesis of metal borides. Solid State Sci. 2003, 5, 925-930. [CrossRef]

30. Wang, M.; Li, H.; Wu, Y.; Zhang, J. Comparative studies on the catalytic behaviors between the Ni-B amorphous alloy and other Ni-based catalysts during liquid phase hydrogenation of acetonitrile to ethylamine. Mater. Lett. 2003, 57, 2954-2964. [CrossRef]

31. Zhao, Y.; Zhao, Y.P.; Feng, H.G.; Shen, J.Y. Synthesis of nickel phosphide nano-particles in a eutectic mixture for hydrotreating reactions. J. Mater. Chem. 2011, 21, 8137-8145. [CrossRef]

32. Guo, L.; Bao, X.J.; Fan, Y.; Shi, G.; Liu, H.Y.; Bai, D.J. Impact of cationic surfactant chain length during SAPO-11 molecular sieve synthesis on structure, acidity, and n-octane isomerization to di-methyl hexanes. J. Catal. 2012, 294, 161-170. [CrossRef]

33. Chen, L.F.; Zhou, X.L.; Noreña, L.E.; Wang, J.A.; Navarrete, J.; Salas, P.; Montoya, A.; Angel, P.D.; Llanos, M.E. Comparative studies of Zr-based MCM-41 and MCM-48 mesoporous molecular sieves: Synthesis and physicochemical properties. Appl. Surf. Sci. 2006, 253, 2443-2451. [CrossRef]

34. Gu, Y.; Liu, S.; Li, C.; Cui, Q. Selective conversion of glycerol to acrolein over supported nickel sulfate catalysts. J. Catal. 2013, 301, 93-102. [CrossRef]

35. Chakraborty, B.; Viswanathan, B. Surface acidity of MCM-41 by in situ IR studies of pyridine adsorption. Catal. Today 1999, 49, 253-260. [CrossRef]

36. Kim, Y.T.; Jung, K.D.; Park, E.D. Gas-phase dehydration of glycerol over ZSM-5 catalysts. Micropor. Mesoporous Mater. 2010, 131, 28-36. [CrossRef]

37. Cai, C.; Wang, H.; Han, J. Synthesis and characterization of ionic liquid-functionalized alumino-silicate MCM-41 hybrid mesoporous materials. Appl. Surf. Sci. 2011, 257, 9802-9808. [CrossRef]

38. Cecilia, J.A.; Jiménez-Morales, I.; Infantes-Molina, A.; Rodríguez-Castellón, E.; Jiménez-López, A. Influence of the silica support on the activity of $\mathrm{Ni}$ and $\mathrm{Ni}_{2} \mathrm{P}$ based catalysts in the hydrodechlorination of chlorobenzene. Study of factors governing catalyst deactivation. J. Mol. Catal. A Chem. 2013, 368-369, 78-87. [CrossRef]

39. Chen, J.X.; Ci, D.H.; Wang, R.J.; Zhang, J.Y. Hydrodechlorination of chlorobenzene over $\mathrm{NiB} / \mathrm{SiO}_{2}$ and $\mathrm{NiP} / \mathrm{SiO}_{2}$ amorphous catalysts after being partially crystallized: A consideration of electronic and geometrical factors. Appl. Surf. Sci. 2008, 255, 3300-3309. [CrossRef] 
40. Lyu, Y.C.; Yu, Z.M.; Yang, Y.; Wang, X.H.; Zhao, X.X.; Liu, X.M.; Yan, Z.F. Metal-acid balance in the in-situ solid synthesized Ni/SAPO-11 catalyst for n-hexane hydroisomerization. Fuel 2019, 243, 398-405. [CrossRef]

41. Boskovic, G.; Micic, R.; Pavlovic, P.; Putanov, P. n-Hexane isomerization over Pt-Na(H)Y catalysts obtained by different preparation methods. Catal. Today 2001, 65, 123-128. [CrossRef]

(C) 2020 by the authors. Licensee MDPI, Basel, Switzerland. This article is an open access article distributed under the terms and conditions of the Creative Commons Attribution (CC BY) license (http://creativecommons.org/licenses/by/4.0/). 